\title{
Strategi Pengembangan Wisata Alam Hutan Irup Desa Saribaye, Kecamatan Lingsar, Lombok Barat
}

\author{
Embun Suryani, Lalu Muhammad Furkan, Diswandi
}

Fakultas Ekonomi dan Bisnis, Universitas Mataram, Mataram, Indonesia

\section{Kata Kunci: \\ wisata alam hutan irup, strategi pengembangan, analisis SWOT}

\begin{abstract}
Abstrak:
Wisata alam berbasis hutan saat ini banyak diminati oleh para wisatawan baik lokal maupun mancanegara. Lombok Barat sendiri memiliki wilayah hutan yang cukup luas sekitar 43,34\% dari total luas wilayahnya. Desa Saribaye yang terletak di kecamatan Lingsar, kabupaten Lombok Barat merupakan salah satu desa yang menyumbang sekian hektar hutan di Lombok Barat. Hutan tersebut memiliki potensi untuk dikembangkan menjadi lokasi wisata alam hutan karena hutan ini dikelilingi oleh aliran sungai jernih, sawah hijau, dan ditumbuhi oleh berbagai pepohonan rimbun. Hutan Irup seringkali dijadikan sebagai lokasi untuk melaksanakan camping namun belum banyak dikenal oleh masyarakat luas. Selama beberapa tahun belakangan ini, Hutan Irup sudah diwacanakan akan dijadikan sebagai lokasi wisata hutan utama untuk desa Saribaye. Oleh karena itu, analisis strategi pengembangan Hutan Irup sebagai lokasi wisata alam perlu dilakukan untuk menunjang keberhasilan pembangunan wisata Hutan Irup. Oleh karena itu, dalam penelitian kali ini akan dirancang suatu strategi untuk mengembangkan wisata alam Hutan Irup dengan menggunakan analisis SWOT.
\end{abstract}

Korespondensi: embunsuryani@unram.ac.id

\section{PENDAHULUAN}

NTB merupakan salah satu daerah yang sangat potensial untuk dikembangkan menjadi daerah wisata karena keindahan alam dan budaya yang dimiliki. Menurut Dinas Kebudayaan dan Pariwisata NTB (2017), jumlah kunjungan wisatawan ke NTB adalah sebesar 3.094.437 dan tidak berbeda signifikan dengan jumlah wisatawan yang mengunjungi Bali yaitu sekitar 4.904.175. Letak geografis NTB yang berdekatan dengan Bali menjadi salah satu faktor keberhasilan yang menunjang NTB menjadi salah satu daerah dengan kunjungan wisatawan yang cukup tinggi karena dianggap sebagai salah satu pariwisata alternatif setelah Bali (Jaelani, 2018). Bahkan sejak tahun 2016 di bawah kepemimpinan Tuan Guru Bajang (TGB), NTB telah mengembangkan suatu konsep wisata halal untuk menarik minat para wisatawan berkunjung ke NTB. Konsep wisata halal tersebut berhasil meningkatkan kunjungan para wisatawan dari rata-rata 400 ribu per tahun menjadi sekitar 3.2 juta per tahun (Redaksi Qultumedia, 2018). Melihat tingginya kunjungan wisatawan di Indonesia khususnya NTB, tidak menutup kemungkinan bahwa sektor pariwisata akan menjadi sumber pendapatan negara nomer satu di Indonesia (Kementrian Pariwisata, 2016).

Salah satu daerah pariwisata yang dikenal di NTB adalah pariwisata di pulau Lombok. Hampir seluruh kabupaten di Lombok menyediakan berbagai macam jenis wisata dan Lombok Barat merupakan salah satu daerah yang banyak menawarkan jenis wisata tersebut mulai dari wisata pantai, wisata air terjun, wisata cagar budaya dan hutan wisata. 
Menurut Badan Pusat Statistik (2016), Lombok Barat merupakan daerah NTB yang memiliki objek wisata terdata terbanyak kedua setelah Lombok Timur yaitu sebanyak 64 objek wisata.

Dari beberapa jenis wisata yang ada, wisata alam hutan merupakan salah satu jenis wisata yang saat ini sedang banyak dikembangkan di Indonesia. Kementrian Lingkungan Hidup dan Kehutanan (Kementrian LHK) (2015) menyebutkan bahwa jumlah wisatawan lokal yang datang berkunjung ke pariwisata berbasis hutan adalah sekitar 4 juta orang dan wisatawan mancanegara diperkirakan sebanyak 3000.00 orang. Kementrian LHK juga mengharapkan bahwa jumlah wisatawan akan meningkat sebesar $40 \%$ dari tahun sebelumnya. Menurut Forest Watch Indosesia, Lombok Barat sendiri memiliki kawasan hutan seluas $43,34 \%$ dari total luas wilayahnya. Oleh karena itu, pengembagan wisata alam hutan menjadi peluang besar dalam mengembangkan potensi hutan wisata di Lombok Barat. Saat ini, hutan di Lombok Barat yang telah dikembangkan menjadi hutan wisata adalah hutan Suranadi dan hutan Sesaot.

Selain kedua hutan tersebut, terdapat pula Hutan Irup yang belum begitu dikenal oleh masyarakat luas tetapi memiliki potensi untuk dikembangkan menjadi hutan wisata. Hutan ini terletak di desa Saribaye, kecamatan Lingsar, kabupaten Lombok Barat. Lokasi desa Saribaye yang strategis hanya $14 \mathrm{~km}$ dari kota Mataram merupakan salah satu faktor pendukung untuk mengembangkan Hutan Irup menjadi daerah wisata khususnya wisata alam hutan. Keistimewaan objek wisata ini adalah dialiri oleh sungai dengan air yang jernih dan debit relative yang tersedia sepanjang tahun. Keistimewaan lain obyek wisata ini adalah ditumbuhi oleh pepohonan besar yang kokoh dan rimbun yang sangat mendukung setiap wisatawan untuk beristirahat dengan nyaman. Oleh sebab itu potensi wisata alam ini perlu dikembangkan dengan melibatkan semua stake holder, sehingga obyek wisata baru ini dapat menjadi trade marker wisata desa Saribaye. Melalui pemaparan tersebut, maka dilakukan sebuah penelitian yang bertujuan untuk merancang strategi pengembangan wisata alam Hutan Irup desa Saribaye, yang nantinya dapat dimanfaatkan sebagai panduan dasar pengembangan wisata Hutan irup pada waktu yang akan datang.

\section{METODE KEGIATAN}

Kegiatan Pengabdian Kepada Masyarakat ini dilakukan di Desa Saribaye, Kecamatan Lingsar, Kabupaten Lombok Barat dari bulan Januari 2019 hingga Maret 2019. Jenis penelitian yang digunakan adalah penelitian deskriptif dengan metode observasi secara langsung pada lokasi Hutan Irup dan melakukan pendekatan dengan metode Focus Group Discussion (FGD).

Metode yang digunakan untuk mengembangkan strategi pengembangan Hutan Irup sebagai daerah wisata alam dilakukan dengan analisis SWOT. Analisis ini merupakan suatu analisis yang dapat menggambarkan kekuatan dan peluang dari objek wisata yang akan dikembangkan dengan mempertimbangkan ancaman serta kelemahan dari objek wisata itu sendiri (Delita dkk., 2017).

\section{HASIL DAN PEMBAHASAN}

Desa Saribaye berjarak kurang lebih $14 \mathrm{~km}$ dari kota Mataram dan membutuhkan waktu tempuh sekitar 20-30 menit dengan kendaraan bermotor. Sementara itu, Hutan Irup 
yang terletak di sebelah utara kantor desa Saribaye dengan jarak $\pm 500 \mathrm{~m}$ hanya membutuhkan waktu tempuh sekitar 10-15 menit untuk mencapai lokasi dengan berjalan kaki. Jalan yang ditempuh dari kantor desa menuju hutan terbilang cukup mudah karena hanya melewati pematang sawah yang mengitari Hutan Irup (Gambar 1). Selama menempuh perjalanan menuju Hutan Irup, wisatawan akan disuguhkan pemandangan yang sangat menarik karena banyaknya hamparan sawah serta pepohonan yang menjulang tinggi (Gambar $1)$.

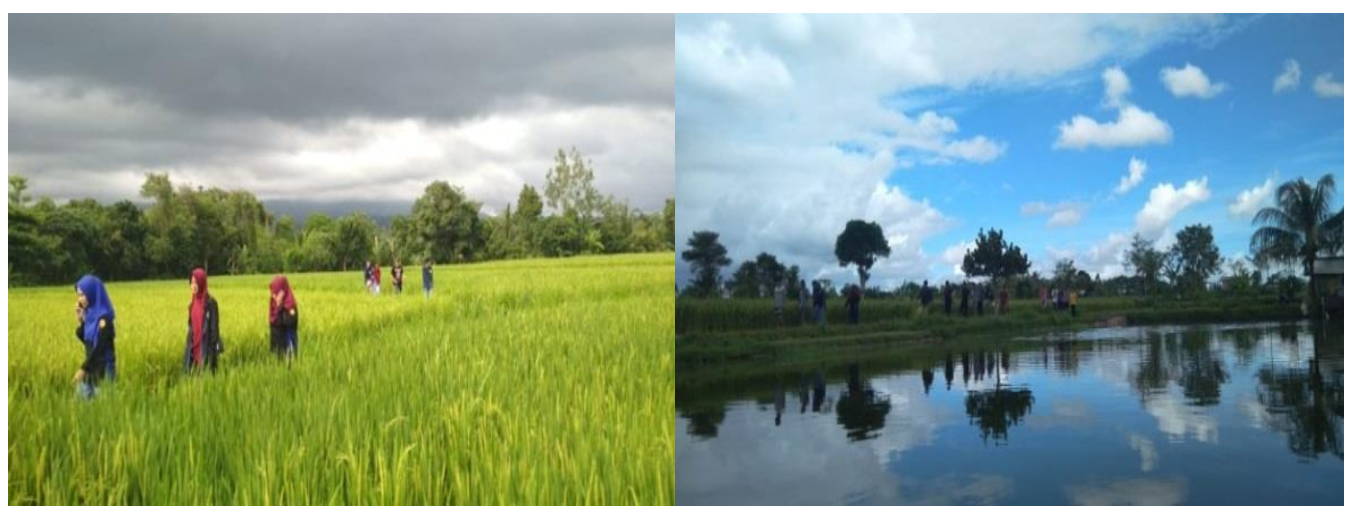

Gambar 1. Perjalanan Menuju Hutan Irup

Dari hasil observasi dan pendekatan FGD di Desa Saribaye diperoleh informasi terkait potensi-potensi yang dapat dikembangkan di Hutan Irup. Beberapa potensi tersebut menununjukkan bahwa Hutan Irup dapat dijadikan sebagai lokasi camping ground, dapat dibangun rumah pohon untuk dijadikan sebagai homestay, dijadikan sebagai lokasi outbond, jalur rafting, pemandian, dan lokasi memancing.

\section{- Lokasi Camping Ground}

Hutan Irup yang memiliki luas sekitar? Ha memiliki spot tanah lapang yang cukup luas sehingga sangat cocok untuk dijadikan sebagai camping ground bersama keluarga maupun teman sejawat Hutan ini juga dialiri dengan aliran sungai jangkok yang jernih (Gambar 2).

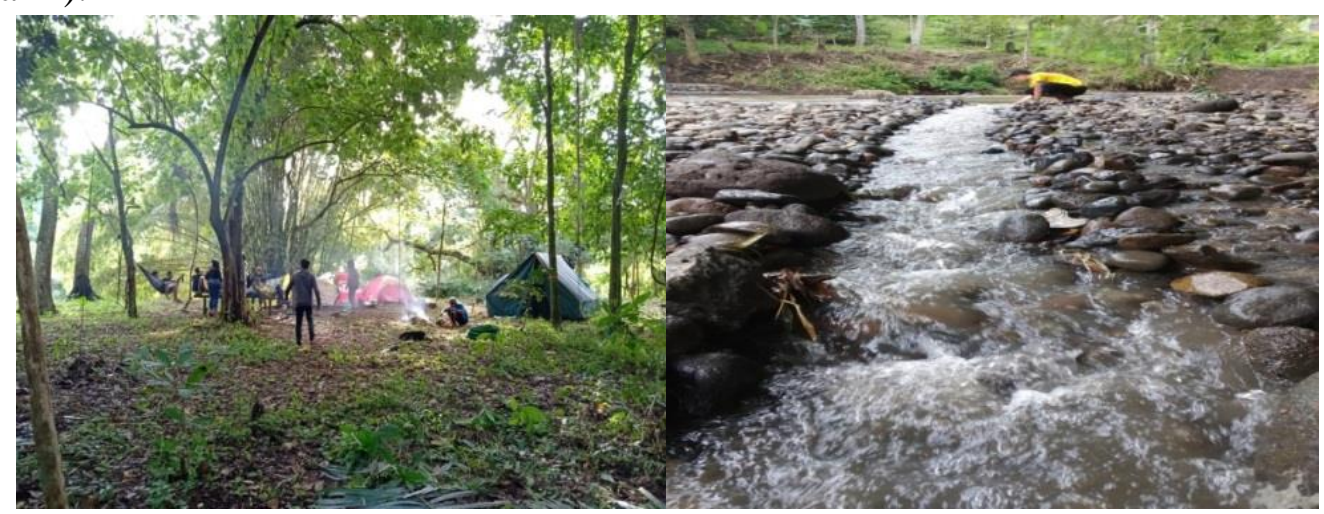

Gambar 2. Lokasi Camping Ground dan aliran Sungai Jangkok di Hutan Irup

Saat ini, keberadaan Hutan Irup hanya sekedar diketahui oleh penduduk yang tinggal disekitar daerah Saribaye. Hutan Irup belum dikenal luas oleh masyarakat sebagai lokasi untuk melaksanakan camping. Walaupun begitu, Hutan Irup sudah beberapa kali digunakan sebagai lokasi camping. Salah satu kelompok yang pernah melaksanakan camping di hutan 
Irup adalah kelompok mahasiswa Biologi dari Universtas Mataram, kelompok karang taruna desa Saribaye, dan yang terakhir kali adalah kegiatan camping yang dilaksanakan oleh karang taruna, mahasiswa KKN tematik unram periode 2018/2019, dan mahaiswa KKN PAR IAIH NW Pancor periode 2018/2019.

Semua kegiatan yang dilaksanakan di Hutan Irup terutama kegiatan camping merupakan salah satu bentuk promosi yang dapat dilakukan untuk memperkenalkan Hutan Irup sebagai camping ground. Semua dokumentasi kegiatan dapat diperlihatkan di media sosial sehingga Hutan Irup bisa menjadi lebih dikenal oleh masyarakat luas.

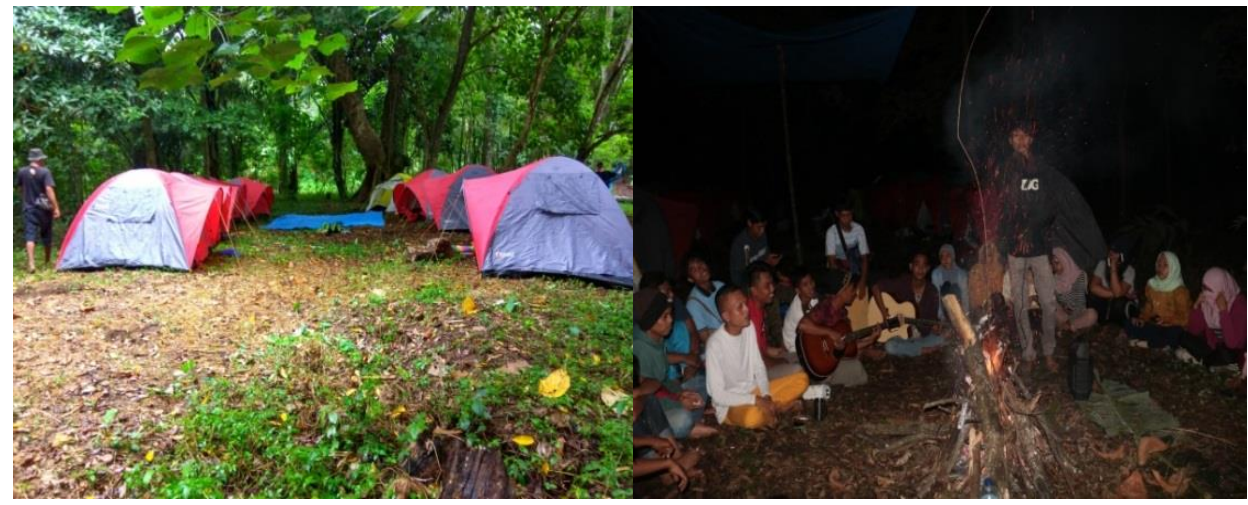

Gambar 3. Kegiatan Camping di Hutan Irup

\section{- Homestay Rumah Pohon}

Bagi para wisatawan yang kemungkinan tidak hobi melakukan camp, Hutan Irup juga dapat mengembangkan pilihan lain seperti Homestay Rumah Pohon. Hutan Irup banyak ditumbuhi oleh pepohonan rindang yang kokoh (Gambar 4). Oleh karena itu sangat memungkinkan untuk membangun rumah pohon yang nantinya dapat menjadi daya tarik tersendiri bagi pengunjung atau wisatawan yang datang ke Hutan Irup. Keberadaan rumah pohon tersebut dapat dimanfaatkan oleh pengelola untuk membuat suatu program wisata yang dapat ditawarkan kepada wisatawan untuk dapat menikmati pemandangan Hutan Irup dan sekitarnya selama beberapa hari dengan cara menginap di Rumah pohon dan tidak hanya sekedar membangun tenda.

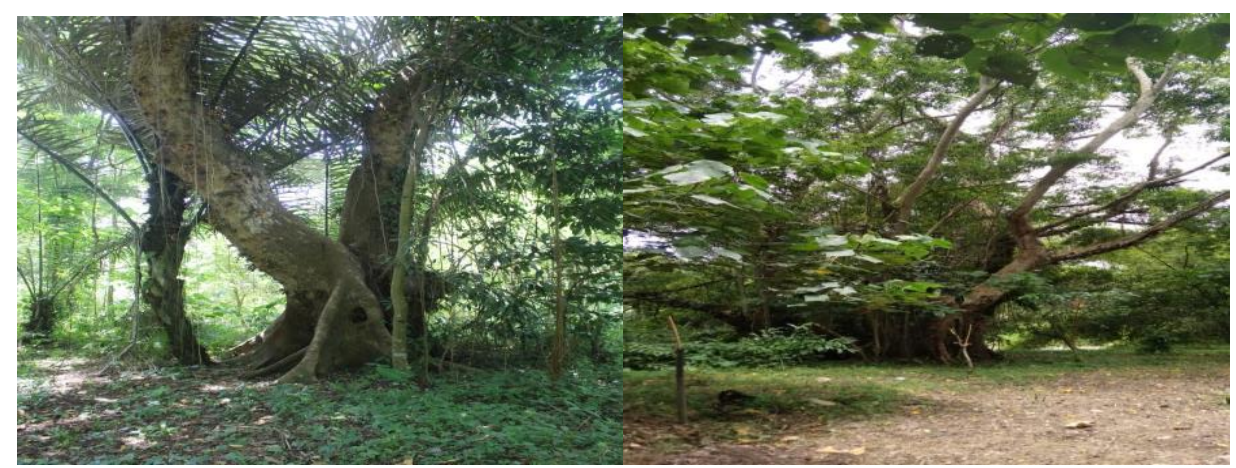

Gambar 4. Salah Satu Pohon di Hutan Irup yang Dapat Dibangunkan Rumah Pohon

\section{- Lokasi Outbond}

Outbond merupakan salah satu fasilitas wisata yang kerap kali dijadikan sebagai pertimbangan oleh masyarakat untuk mengunjunggi suatu lokasi wisata. Adanya fasilitas 
outbond ditujukan agar wisatawan yang dating berkunjung merasa senang, puas, dan merasa ingin dating kembali untuk berkunjung (Kurniawan, 2015). Geografis dari hutan Irup yang lokasinya cukup tinggi dan luas menyebabkan Hutan ini menjadi lokasi yang cocok untuk membangun berbagai jenis outbond seperti misalnya flying fox dan berbagai jenis game lainnya seperti game yang bersifat character building maupun games mendidik lainnya.

\section{- Jalur Rafting / Arum Jeram, Lokasi Pemandian dan Lokasi Memancing}

Seperti telah dijelaskan sebelumnya, Hutan Irup dikelilingi oleh aliran sungai Jangkok yang jernih. Aliran sungai ini juga dipenuhi oleh bebatuan yang menambah daya tarik sungai tersebut (Gambar 5). Aliran sungai yang ada pada Hutan Irup merupakan aliran sungai yang berasal dari Kebun Irup (merupakan salah satu wisata yang ada di Saribaye). Aliran sungai tersebut merupakan jalur rafting yang sudah sering kali dilewati oleh pengunjung Kebun Irup. Jalur sungai yang melewati hutan irup inilah yang juga nantinya akan menyebabkan para pengunjung yang sedang melakukan rafting bisa sekaligus melihat suasana wisata alam di Hutan Irup.

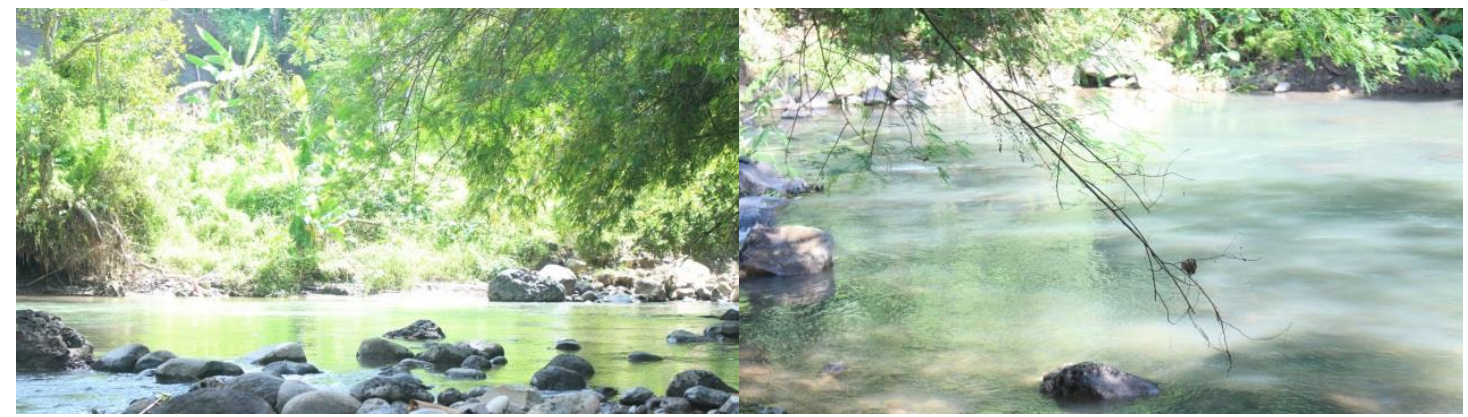

Gambar 5 Sungai Jangkok yang dapat Dimanfaatkan Sebagai Jalur Rafting, Lokasi Pemandian dan Memancing

Selain sebagai jalur rafting, sungai ini juga cocok dijadikan sebagai lokasi untuk memancing dikarenakan banyaknya ikan yang terdapat di sungai. Aliran sungai yang cukup tenang juga menyebabkan sungai ini bisa dijadikan sebagai tempat pemandian ataupun arena permainan air. Melalui potensi-potensi yang telah dipaparkan tersebut, dapat dilihat bahwa Hutan Irup memang memiliki potensi yang sangat besar untuk menjadi lokasi wisata terutama sebagai tempat camping ground. Potensi-potensi tersebut harus terus dikembangkan untuk mewujudkan Hutan Irup sebagai hutan wisata alam yang ramai dikunjungi para wisatawan.

Pengembangan potensi tersebut tentunya harus memperhatikan berbagai aspek seperti kekuatan dari Hutan Irup, kelemahan yang masih harus diatasi di Hutan Irup, peluang yang dapat dijadikan sebagai batu loncatan untuk menjadi lokasi wisata yang lebih baik lagi, maupun kemungkinan-kemungkinan ancaman yang dapat mengganggu atau menjatuhkan Hutan Irup sebagai lokasi wisata. Keempat aspek yang disebutkan tersebut tertuang dalam suatu analisis yang dikenal dengan istilah analisis SWOT (Strenght, weakness, opportunity, and threat).

Analisis SWOT merupakan salah satu identifikasi yang bersifat sistematis dari faktor kekuatan dan kelemahan suatu organisasi ataupun suatu objek serta peluang dan ancaman lingkungan luar strategi (Hamali, 2016). Analisis keempat aspek tersebut dapat diperoleh suatu kombinasi yang tepat untuk merumuskan suatu strategi dalam mengembangkan 
organisasi maupun objek wisata. Tujuan dari analisis SWOT ini adalah untuk dijadikan sebagai acuan, gambaran, atau pun arahan dalam mengembangkan suatu hal dan bukan untuk dijadikan sebagai pemecah masalah. Melalui observasi dan FGD yang dilakukan selama kurang lebih satu setengah bulan, hasil analisis SWOT yang diperoleh untuk Hutan Irup disajikan pada Tabel 1 .

Tabel 1. Analisis SWOT Pengembangan Hutan Irup Sebagai Objek Wisata Baru

\begin{tabular}{|c|c|}
\hline $\begin{array}{l}\text { Strenght (S) } \\
\text { - Lokasi strategis dan dekat dengan kota } \\
\text { - Lingkungan yang masih asri } \\
\text { - } \text { Udara yang bersih dan sejuk } \\
\text { - Pemandangan yang indah } \\
\text { - Terdapat aliran sungai yang jernih } \\
\text { - Terdapat pepohonan kokoh dan rindang } \\
\text { - Kondisi aman } \\
\text { - Semua potensi yang telah disebutkan } \\
\text { sebelumya }\end{array}$ & $\begin{array}{l}\text { Weakness (W) } \\
\text { - Sarana dan prasarana belum memadai } \\
\text { - Warga sekitar belum belum } \\
\text { sepenuhnya menyadari potensi Hutan } \\
\text { Irup } \\
\text { - Kurangnya perawatan terhadap lokasi } \\
\text { wisata Hutan Irup } \\
\text { - Tidak ada objek wisata pendamping } \\
\text { seperti spot selfie maupun atraksi } \\
\text { pendamping lainnya di lokasi Hutan } \\
\text { Irup } \\
\text { - Belum ada transportasi khusus untuk } \\
\text { menuju lokasi wisata Hutan Irup }\end{array}$ \\
\hline $\begin{array}{l}\text { Oppurtunity (O) } \\
\text { - } \text { Adanya rencana pemerintah desa untuk } \\
\text { mengembangkan wisata alam Hutan Irup } \\
\text { - Dapat membuka lapangan kerja untuk } \\
\text { warga sekitar yang bertempat tinggal di } \\
\text { Hutan Irup } \\
\text { - Minat masyarakat terutama masyarakat kita } \\
\text { - } \text { untuk wisata alam semakin meningkat } \\
\text { Hutan dibuatkan paket wisata karena lokasi } \\
\text { yang telah lebih banyak dikenal }\end{array}$ & $\begin{array}{l}\text { Threat (T) } \\
\text { - Terdapat objek wisata lain yang sudah } \\
\text { terlebih dahulu dikembangkan di } \\
\text { Lombok Barat seperti di suranadi dan } \\
\text { Sesaot. } \\
\text { - Air sungai bisa saja meluap apabila } \\
\text { musim hujan tiba }\end{array}$ \\
\hline
\end{tabular}

Dengan memperhatikan hasil dari analisis SWOT tersebut, beberapa strategi yang dapat dikembangkan atau dilaksanakan dapat dirumuskan dengan lebih terstruktur. Jadi, beberapa strategi pengembangan wisata alam Hutan Irup berdasarkan Analisis SWOT adalah sebagai berikut:

\section{1) Pembangunan sarana dan prasarana yang memadai}

Keberadaan sarana dan prasarana yang memadai merupakan salah satu faktor penting yang dapat menarik para wisatawan untuk berkunjung ke suatu objek wisata (Delita dkk, 2017). Sarana dan prasarana yang baik dan memadai merupakan salah satu bentuk pelayan yang dapat ditawarkan kepada wisatawan yang berkunjug. Jadi semakin baik sarana dan prasaran yang ada, tingkat kepuasan wisatawan akan semakin meningkat dan akan semakin baik pula kesan yang dapat ditinggalkan wisatawan terhadap lokasi wisata yang dikunjungi 
(Soebiantoro, 2009). Pada objek wisata Hutan Irup sendiri, sarana dan prasarana masih belum cukup memadai. Melalui proses observasi, analisis SWOT, diskusi dengan tokoh desa dan warga sekitar Saribaye, disimpulkan beberapa sarana dan prasarana yang perlu dibangun di Hutan Irup untuk memaksimalkan tempat ini sebagai lokasi wisata adalah sebagai berikut:

- Jalan dan transportasi untuk mempermudah wisatawan menuju lokasi Hutan Irup.

Selain berjalan kaki menuju lokasi Hutan Irup, tidak menutup kemungkinan jika para wisatawan yang berdatangan juga menginginkan fasilitas transportasi untuk menuju Hutan Irup. Agar tidak menghilangkan ciri khas pedesaan maka sepedah menjadi salah satu pilihan utama untuk disediakan sebagai alat transportasi. Sepedah dipilih dikarenakan sepedah bersifat lebih ramah lingkungan dan lokasi Hutan Irup yang tidak begitu jauh dari pusat desa (Kantor Desa). Oleh karena itu, jalanan yang dibangun disarankan berupa jalan yang mudah dilalui oleh sepedah. Jadi para wisatawan dapat bersepedah untuk menuju lokasi wisata dengan tetap dapat menikmati keindahan alam sekitar selama perjalananan.

- Pencarian Mata Air dan Pembangunan MCK (Mandi Cuci Kakus).

Sumber mata air digunakan untuk mengaliri MCK. MCK merupakan salah satu fasilitas umum yang selalu dibutuhkan pada komdisi apapun. Pembangunan MCK ini ditujukan untuk memberikan kenyamanan bagi para wisatawan yang datang berkunjung ke Hutan Irup.

- Lokasi Pembayaran Karcis.

Sebagai lokasi wisata, tentunya karcis merupakan salah satu sarana paling dibutuhkan untuk memberi keuntungan bagi pengolah wisata yaitu Desa Saribaye sendiri. Pembangunan untuk loket karcis

- Loket Penyewaan Tenda.

Dikarenakan Pembangunan Hutan Irup ditujukan untuk wisata alam, maka loket penyewaan tenda disekitar lokasi Hutan Irup sangat diperlukan mengingat Hutan Irup ini juga akan dikembangkan menjadi camping ground. Pembangnan loket penewaan tenda ini nantinya daa menunjang fungsi Hutan Irup sebagai lokasi wisata alam.

\section{2) Mengoptimalkan Seluruh Potensi Wisata pada Hutan Irup}

Segala potensi yang disebutkan sebelumnya merupakan salah satu kekuatan atau daya tarik yang dimiliki oleh Hutan Irup. Memaksimalkan segala potensi tersebut merupakan salah satu langkah yang dapat dilakukan sehingga Hutan Irup memiliki suatu aktivitas yang dapat ditawarkan ke masyarakat luas yang datang berkunjung untuk melakukan perjalanan wisata.

\section{3) Melakukan Kerja Sama dengan Pihak Terkait}

Pihak terkait yang dimaksud adalah instansi pemerintah yang memiliki kewenangan dalam mengatur pariwisata di Indonesia seperti dinas pariwisata dan kebudayaan provinsi maupun kabupaten. Pihak-pihak tersebut nantinya diharapkan akan mendukung keberlangsungan pengembangan Hutan Irup sebagai lokasi wisata yang ada di NTB khususnya Lombok Barat. Selain itu, kerjasama dengan pihak swasta sangat diperlukan untuk mengkoordinasikan penyelenggaraan kepariwisataan terutama dalam penyelenggaraan sarana dan prasarana maupun jasa kepariwisataan (Zulfikar, 2017). 


\section{4) Memaksimalkan Sumber Daya Manusia (SDM) Saribaye dan Tenaga Kerja Profesional}

Selain mengoptimalkan sumber daya alam yang ada, sumber daya manusia juga perlu dimaksimalkan fungsinya agar pengelolaan sumber daya alam juga menjadi maksimal. Sumber daya manusia yang terampil dan sadar akan pentingnya wisata akan dapat menghasilkan suatu objek wisata yang akan berkesan di mata wisatawan yang berkunjung.

Salah satu langkah yang dapat ditempuh untuk mengoptimalkan fungsi SDM di Saribaye adalah dengan cara membentuk kelompok sadar wisata (Pokdarwis) Saribaye yang nantinya akan bertanggung jawab dalam mengelola pariwisata yang ada. Pokdarwis ini juga yang nantinya akan mengembangkan, melahirkan inovasi, dan terus memberdayakan pariwisata khususnya pariwisata Hutan Irup di Saribaye.

SDM yang terlibat di dalam organisasi pokdarwis diharpakan pula merupakan seorang tenaga professional sehingga seluruh perencanaan pengembanga, pengelolaan, inovasi dan pemeliharaan objek wisata yang ada tetap dilaksanakan dengan sebaik-baiknya dan secara berkesinambungan.

\section{5) Membangun Sektor Usaha}

Keberadaan pariwisata di suatu daerah pada umumnya akan membuka lapangan kerja terutama bagi masyarakat sekitar yang tinggal di daerah wisata tersebut. Selain membuka lapangan pekerjaan, pembangunan sektor usaha di lokasi wisata terutama dalam bidang pangan dan cendramata merupakan salah satu strategi yang dapat dimanfaatkan untuk meningkatkatkan daya tarik wisatawan terhadap suatu objek wisata.

Hal tersebut disebabkan karena pada umumnya wisatawan yang berkunjung akan mencari suatu yang khas dari objek wisata yang akan dikunjunginya. Jadi, untuk memaksimalkan Hutan Irup sebagai lokasi wisata alam maka sektor usaha yang dapat menunjukkan ciri khas Saribaye seperti makanan ataupun cendramata dapat dibangun disekitar lokasi wisata ataupun menyebar di Desa Saribaye itu sendiri.

\section{6) Memaksimalkan Pariwisata Pendukung/Pendamping}

Pariwisata pendukung yang dimaksud adalah objek-objek menarik yang ada di Desa Saribaye. Pariwisata pendukung ini harus dikembangkan dengan tujuan untuk menahan para wisatawan lebih lama berada di lokasi wisata. Objek tersebut dapat berupa kebudayaan, kerajinan, maupun kuliner. Salah satu dusun yang ada di desa Saribaye yaitu dusun Nirbaye merupakan dusun yang terkenal dengan anyaman ketak.

Anyaman ketak yang dihasilkan oleh para produsen di dusun Nirbaye banyak diekspor ke luar negeri terutama Jepang. Selain itu, di dusun ini dikembangkan pula cendramata berupa lukisan kayu yang juga banyak diekspor ke luar negeri. Dalam rangka meningkatkan eksistensi ketak dan lukisan kayu di desa Saribaye, pembangunan artshop dapat dilakukan sehingga para wisatawan yang berkunjung ke Hutan Irup ataupun Saribaye dapat berjalan keliling desa untuk melihat cendramata khas desa Saribaye.

Selain cendramata, terdapat pula suatu kesenaian khas Saribaye yang berpusat di Dusun Sandongan. Kesenian tersebut adalah Kayaq Sandongan yang mirip dengan wayang 
namun bedanya Kayak Sandongan ini diperankan langsung oleh manusia. Kayaq Sandongan merupakan kesenian yang diperkirakan sudah berumur ratusan tahun.

Dengan mempertahankan keberadaan Kayak Sandongan dan Kerajinan khas Saribaye diharapkan pilihan objek wisata yang dikunjungi wisatawan akan semakin beragam pula tidak hanya sekedar berkunjung ke Hutan Irup untuk melakukan camping.

\section{7) Meningkatkan Promosi}

Menurut Sunyoto (2009), promosi merupakan suatu kegiatan yang dilakukan untuk mempengaruhi, memberitau, ataupun memperkenalkan suatu objek kepada masyarakat luas. Kegiatan promosi ini pun sangat diperlukan dalam dunia pariwisata untuk memperkenalkan objek maupun daerah wisata. Jadi, dikenalnya suatu objek maupun daerah wisata tidak lepas dari proses promosi yang berhasil.

Oleh karena itu, untuk memperkenalkan Hutan Irup dan segala objek wisata yang ada di desa Saribaye, maka proses promosi yang berkaitan dengan objek wisatanya harus gencar dilakukan. Media promosi yang sangat digencarkan saat ini adalah media promosi melalui sosial media baik melalui instagram, twitter, facebook, maupun media sosial lainnya. Selain melalui sosial media, pembuatan website resmi untuk pariwisata desa Saribaye dapat dilakukan sehingga seseorang akan lebih mudah untuk mengakses informasi terkait denga objek wisata yang ada di Saribaye.

\section{KESIMPULAN DAN SARAN}

Kesimpulan yang dapat diperoleh dari pelaksanaan program pengabdian kepada masyarakat "Berdaya Desa Melalui Pengolahan Potensi Lokal (Abon Ikan Nila) Dalam Rangka Penguatan Ekonomi Ibu Rumah Tangga di Desa Saribaye" adalah:

1. Minat yang tinggi dari mitra program pengabdian kepada masyarakat memberikan dampak positif bagi pelaksanaan program, terlihat dari pelatihan dan pendampingan selama pelatihan pembuatan abon dari potensi lokal desa, yakni ikan nila.

2. Pelaksanaan program mampu menghasilakan luaran-luaran yang diharapkan oleh program pengabdian kepada masyarakat ini, berupa produk potensi lokal yang dapat meningkatkan dikomersialisasikan, sehingga adanya penguatan ekonomi ibu-ibu rumah tangga di Desa Saribaye.

Saran yang dapat diberikan penulis untuk keberlanjutan program pengabdian kepada masyarakat ini :

1. Adanya pendampingan kepada ibu-ibu mengenai manajemen usaha lanjutan sampai mendapatkan izin MUI.

2. Adanya inovasi produk produk olahan lanjutan berbahan dasar ikan nila sebagai potensi lokal desa.

\section{DAFTAR PUSTAKA}

Dinas Kelautan dan Perikanan Provinsi NTB Satker Dinas Perikanan dan Kelautan Provinsi NTB, 2008. Identifikasi Potensi Budidaya Air Payau NTB Tahun 2008. Laporan. Dinas Kelautan dan Perikanan Provinsi NTB. Mataram. 
Dinas Kelautan dan Perikanan Provinsi NTB Satker Dinas Perikanan dan Kelautan Provinsi NTB, 2008. Identifikasi Potensi Budidaya Air Tawar NTB Tahun 2008. Laporan. Dinas Kelutan dan Perikanan Provinsi NTB.

Ramlah, Ramlah, et al. "Perbandingan Kandungan Gizi Ikan Nila Oreochromis niloticus Asal Danau Mawang Kabupaten Gowa Dan Danau Universitas Hasanuddin Kota Makassar." BIOMA: JURNAL BIOLOGI MAKASSAR 1.1 (2017).

Khairuman, AMd, and Khairul Amri. Budi Daya Ikan Nila Secara Intensif. AgroMedia, 2005.

Ningsih, Novia, La Nalefo, and Ima Astuty Wunawarsih. "Efektivitas Metode Kelompok terhadap Peningkatan Pengetahuan Wanita Tani dalam Pemanfaatan Lahan Pekarangan di Desa Kalimas Kecamatan Kaledupa Kabupaten Wakatobi." Jurnal Ilmiah Membangun Desa dan Pertanian 4.2 (2019). 